\title{
Integrated Reporting for a Re-Imagined Capitalism
}

\section{Citation}

Eccles, Robert G., and Birgit Spiesshofer. "Integrated Reporting for a Re-Imagined Capitalism." Harvard Business School Working Paper, No. 16-032, September 2015.

\section{Permanent link}

http://nrs.harvard.edu/urn-3:HUL.InstRepos:22824053

\section{Terms of Use}

This article was downloaded from Harvard University's DASH repository, and is made available under the terms and conditions applicable to Open Access Policy Articles, as set forth at http:// nrs.harvard.edu/urn-3:HUL.InstRepos:dash.current.terms-of-use\#OAP

\section{Share Your Story}

The Harvard community has made this article openly available.

Please share how this access benefits you. Submit a story.

Accessibility 


\section{Integrated Reporting for a Re- Imagined Capitalism}

Robert G. Eccles Birgit Spiesshofer

Working Paper 16-032 


\title{
Integrated Reporting for a Re-Imagined Capitalism
}

\author{
Robert G. Eccles
}

Harvard Business School

Birgit Spiesshofer

DENTONS

Working Paper 16-032 


\title{
Integrated Reporting for a Re-Imagined Capitalism
}

Robert G. Eccles and Birgit Spiesshofer

\begin{abstract}
An essential element of capitalism is corporate reporting. Today's capitalism is supported by financial reporting. Critics of today's capitalism argue that it is too shortterm oriented and rewards companies for creating negative externalities. Integrated reporting can play an important role in changing this since it is focused on the material issues that affect a company's ability to create value over the short, medium, and long term. Each country must take its own path to integrated reporting. This is illustrated by analyzing the different regulatory and legislative regimes in the United States and the European Union.
\end{abstract}

Keywords: Integrated reporting, materiality, Securities and Exchange Commission, European Union, information and transformation function

\section{Introduction}

The essence of a re-imagined capitalism lays in resource allocation decisions that go beyond short-term financial performance. Achieving this will require companies and investors to take a longer-term view and use a broader range of performance metrics. To do this, they will need information that goes beyond financial metrics, even as this information should be related to financial performance. Substantial changes in internal and external reporting will be required. In this chapter, we make the case for integrated reporting as the type of corporate reporting necessary, although certainly not sufficient, to set the scene for a re-imagined capitalism. In the next section, we describe three types of corporate reporting (financial, sustainability, and integrated) and classify each in terms of corporate reporting's two functions: information and transformation. The subsequent section makes the case for the central role integrated reporting can play in a re-imagined capitalism. We then discuss the feasibility of the U.S. Securities and Exchange 
Commission providing regulatory support for integrated reporting in the United States before analyzing the implications of the Directive 2014/95/EU of 22 October 2014 amending Directive 2013/34/EU as regards disclosure of non-financial and diversity information by certain large undertakings and groups (CSR Reporting Directive) for reporting in the European Union and, in particular, the paradigm shift to new functions of nonfinancial reporting. We conclude with some brief thoughts on what will be required for integrated reporting to become the prevailing practice.

\section{The Types and Functions of Corporate Reporting}

An important element in any form of re-imagined capitalism is corporate reporting. To some, the question of how transparent companies should be about their activities and results is technical, arcane, and even boring. To the initiated, it is a hard-fought terrain defined by the tension between companies, who typically want less transparency, and stakeholders or audiences for the reporting, who want more.

There are three basic types of corporate reporting: (1) financial, (2) sustainability, and (3) integrated. They vary in terms of content, audience, and practice (Figure 1). Today's capitalism is based upon financial reporting, and we would argue that today's capitalism would not exist without financial reporting, which itself is based on accounting standards that must then be reviewed by independent audit firms to produce publicly reported financial performance metrics. Financial reporting should provide investors with information they need to make informed decisions, and listed companies are obligated to follow this practice in order to have access to public capital markets. A vast social infrastructure of securities regulators (e.g., the U.S. Securities and Exchange Commission), accounting standard setting bodies (primarily the U.S. Financial Accounting Standards Board (FASB) )and the International Accounting Standards Board (IASB)), auditing firms (e.g., Deloitte, EY, KPMG, and PricewaterhouseCoopers), and oversight bodies of the accounting profession (e.g., the U.S. Public Company Accounting Oversight Board) support the timely provision of high quality financial information. This infrastructure has been developed over decades. 
Figure 1: Three Types of Corporate Reporting

\begin{tabular}{|c|c|c|c|}
\hline $\begin{array}{c}\text { Type of } \\
\text { Reporting }\end{array}$ & Content & Audience & Practice \\
\hline \hline Financial & Financial Information & Investors & Mandated \\
\hline Sustainability & Nonfinancial Information & Stakeholders & Mostly Voluntary \\
\hline Integrated & $\begin{array}{c}\text { Financial and Nonfinancial } \\
\text { Information }\end{array}$ & $\begin{array}{c}\text { Investors and } \\
\text { Significant } \\
\text { Audiences }\end{array}$ & Mostly Voluntary \\
\hline
\end{tabular}

Sustainability reporting dates only back to the early 1990s. The purpose of sustainability reporting is to provide a broad range of stakeholders with information on a company's performance across a wide range of environmental, social, and governance (ESG) performance dimensions. Although they can have financial implications, these dimensions are typically referred to as "nonfinancial” information. The non-profit Global Reporting Initiative (GRI), founded in 1997, played a central role in its development. CDP, originally called the Carbon Disclosure Project when it was formed in 2001, gave sustainability reporting critical teeth by developing measurement standards for greenhouse gas emissions and, more recently, water and forestry. Today nearly 5,000 companies issue sustainability reports, including $85 \%$ of the world's largest companies. Ten years ago, only 300 companies did so, as calculated by Arabesque Asset Management Ltd. using the GRI reporting database for 2013, 2014 and 2015.

Historically, most investors have had little interest in nonfinancial information, with the Socially Responsible Investment community being an exception. Today, more “mainstream” investors are showing interest in ESG performance. However, their interest lies in a relatively small subset of the total information available in a sustainability report: they want to know about a company's performance on material issues that affect its ability to create and preserve value. Although regulations around sustainability reporting are growing, it largely remains a voluntary practice by companies, although some recent EU legislation, discussed below, will change this. Even when regulations exist, they rarely specify which measurement standards should be used and what the format of the report should be. As a result, it is difficult for investors and other stakeholders to compare the 
performance of companies, even within the same sector, and to find the information of most interest to them.

The newest form of reporting — integrated reporting_dates back to the early 2000s, but has only received broad attention in the past five years. Defined by The International Integrated Reporting Council (IIRC)’s 2013 Framework, “[t]he primary purpose of an integrated report is to explain to providers of financial capital how an organization creates value over time. An integrated report benefits all stakeholders interested in an organization's ability to create value over time, including employees, customers, suppliers, business partners, local communities, legislators, regulators and policy-makers” (IIRC, 2015: 4). Along with GRI, the IIRC (started in 2010), and the Sustainability Accounting Standards Board (SASB, started in 2011), are the two key organizations seeking to spread awareness about and adoption of integrated reporting. Integrated reporting is completely voluntary with the exception of South Africa, where it is required of all companies listed on the Johannesburg Stock Exchange on an "apply or explain” basis (for a fuller discussion of the South African case see Eccles, Krzus, and Ribot, 2015: ch. 1).

In addition to content, audience, and practice, each type of corporate reporting can be understood in terms of the function it fulfills (Figure 2). Eccles and Serafeim (2015) have argued that corporate reporting has two functions: information and transformation. The information function refers to corporate reporting's duty to provide counterparties to the corporation the information they need to make an informed decision on whether to transact with the company and, if so, on what terms. In a corporate reporting context, these counterparties include providers of capital, both equity and debt, as well as vendors, customers, employees, and regulators who are interested in assuring that this information is accurate and provided on a timely basis. The information function is "one-way" in that the company provides the information and the counterparty makes its decision, but with no intent to affect the behavior of the company.

In contrast, the transformation function involves feedback from the counterparty with the intent of changing the company (Eccles and Serafeim, 2015): 
While the information function assumes no feedback from counterparties, the transformation function relaxes this assumption, allowing for engagement and activism from the counterparties. The counterparties receive and evaluate the information. Where they see opportunities to influence corporate behavior to their benefit, and potentially to the benefit of the corporation, they actively try to bring about change. This engagement, activism, and change process enables a company to transform.

The transformation function is a "two-way" street: the company must be open to the feedback it is getting from its counterparties and willing to engage with them. Information is an end in and of itself in the information function; it is a necessary, but not sufficient, condition for the transformation function. While this two-way street is conceptually independent of the information's content, the types of corporate reporting are broadly distinctive in their intended function. The primary application of financial reporting is to provide investors with information to make investment decisions. In providing financial information, the company is not looking for feedback, perhaps other than to verify that it has met the expectations of its investors. It is not seeking input from its investors on how the company can be managed better to improve its financial results. For the most part, investors do not see this as their role. In investor briefings and conference calls, they ask questions - sometimes leading questions_-but do not give advice. Some investors may use financial information to attempt transformation, as an activist investor who takes a large position in the company and then looks to make changes, by putting its own representatives on the board and pressuring the company in other ways, does.

Current practices in financial reporting in the context of earnings guidance and quarterly conference calls that focus almost solely on financial performance reinforces capitalism as we know it today. The obsession of today's capitalism with short-term fluctuations in stock price can be traced to a historical, although by no means inevitable, focus on shortterm investors. Companies take decisions behind corporate castle walls and report on their performance outcomes to satisfy the information function of corporate reporting, and the main feedback the company receives is whether its stock price goes up or down. Sell-side 
analysts' quarterly and annual earnings estimates and relative indifference to ESG issues reinforce today’s capitalism.

Whereas financial reporting is mandated by the State for all listed companies, sustainability reporting originates in the demands of civil society for more transparency by companies about their position and performance on ESG issues. Financial information can be taken for granted; the same is not true for nonfinancial information. Its seekers want information so that they can decide whether to engage with a company in an attempt to changes its practices and behavior. Typically, the focus is on companies seen as underperforming on the topic of interest to the stakeholder. When the company responds to these entreaties, the transformation process begins. Yet, the outcome depends on resources invested by each side of the engagement, which itself is a function of the perceived importance of the issue. Companies must also consider the fact that different stakeholders' interests may be in conflict with each other. Tradeoffs exist. Most often, stakeholders are so focused on their own issues that they are indifferent to this reality.

Sustainability reporting has played an important role in laying the groundwork for a new conception of capitalism since it explicitly recognizes the growing importance of stakeholders focused on ESG issues that matter to society. Because its function is one of transformation, it also opens up companies to engagement, which is a key tenet of any new form of capitalism. Sustainability reporting's main limitation is that it does not distinguish between ESG issues that are material for the company (the province of capitalism) and the socially significant ones (the province of civil society). Capitalism resides within broader civil society, and changing social expectations will have implications for how it is practiced, but the relative indifference of investors to the information contained in a sustainability report indicates that simply pairing sustainability reporting with financial reporting will not contribute to a re-imagined capitalism.

Integrated reporting's primary interest is transformation, albeit from a somewhat different starting place. Sustainability reporting is an "outside-in” approach to transformation. Civil society puts pressure on the company to disclose information that it uses to enact an engagement process that leads to transformation. Integrated reporting is more of an 
"inside-out" approach: advocates for integrated reporting argue that companies should, in the beginning, practice it for their own good. Integrated reporting is argued to be a way of fostering "integrated thinking" so that the company operates in a holistic way, taking account of material ESG issues across the six capitals (financial, manufactured, natural, intellectual, human, and social and relationship) that affect financial performance. It will lead to a better managed company that is more able to create value over the short, medium, and long term, and in doing so, provide the information necessary for its investors to take a longer-term view and to attract more who do. It is a kind of "reverse activism" in which the company is influencing its investor base rather than the other way around.

Figure 2: The Functions of Corporate Reporting

\begin{tabular}{|c|c|}
\hline Type of Reporting & Function \\
\hline \hline Financial & Information \\
\hline Sustainability & Transformation \\
\hline Integrated & Transformation \\
\hline
\end{tabular}

\section{How Integrated Reporting Supports a Re-Imagined Capitalism}

Today many people are seeking to re-imagine capitalism. All such concepts have certain characteristics in common: (1) greater attention to the negative externalities produced by a company and its efforts to mitigate them, (2) greater attention to the interests and expectations of other stakeholders, especially for very large companies, since society increasingly looks to them and not just governments to contribute to sustainable development, (3) striking the proper balance between meeting the expectations of shareholders and other stakeholders, (4) institutional investors factoring in a company's sustainability performance in investment decisions, and (5) a longer-term outlook on the part of both companies and investors.

Integrated reporting supports all of these characteristics. In terms of (1), the "Value Creation Process” in “The International <IR $>$ Framework ( $<$ IR $>$ Framework)” (Figure 3) 
emphasizes that companies use the six capitals as inputs into their business model and have outcomes that impact these capitals. These outcomes are both positive and negative. The <IR> Framework further notes that the company should explain "the interdependencies and trade-offs between the capitals, and how changes in their availability, quality and affordability affect the ability of the organization to create value” (IIRC, 2013: 17). While the <IR> Framework does not specify how the uses and outcomes of these capitals should be measured, it makes clear that the company should take all of them into account. Organizations like CDP, GRI, and SASB are developing measurement and reporting standards to provide guidance to companies for doing this.

\section{Figure 3: The Value Creation Process}

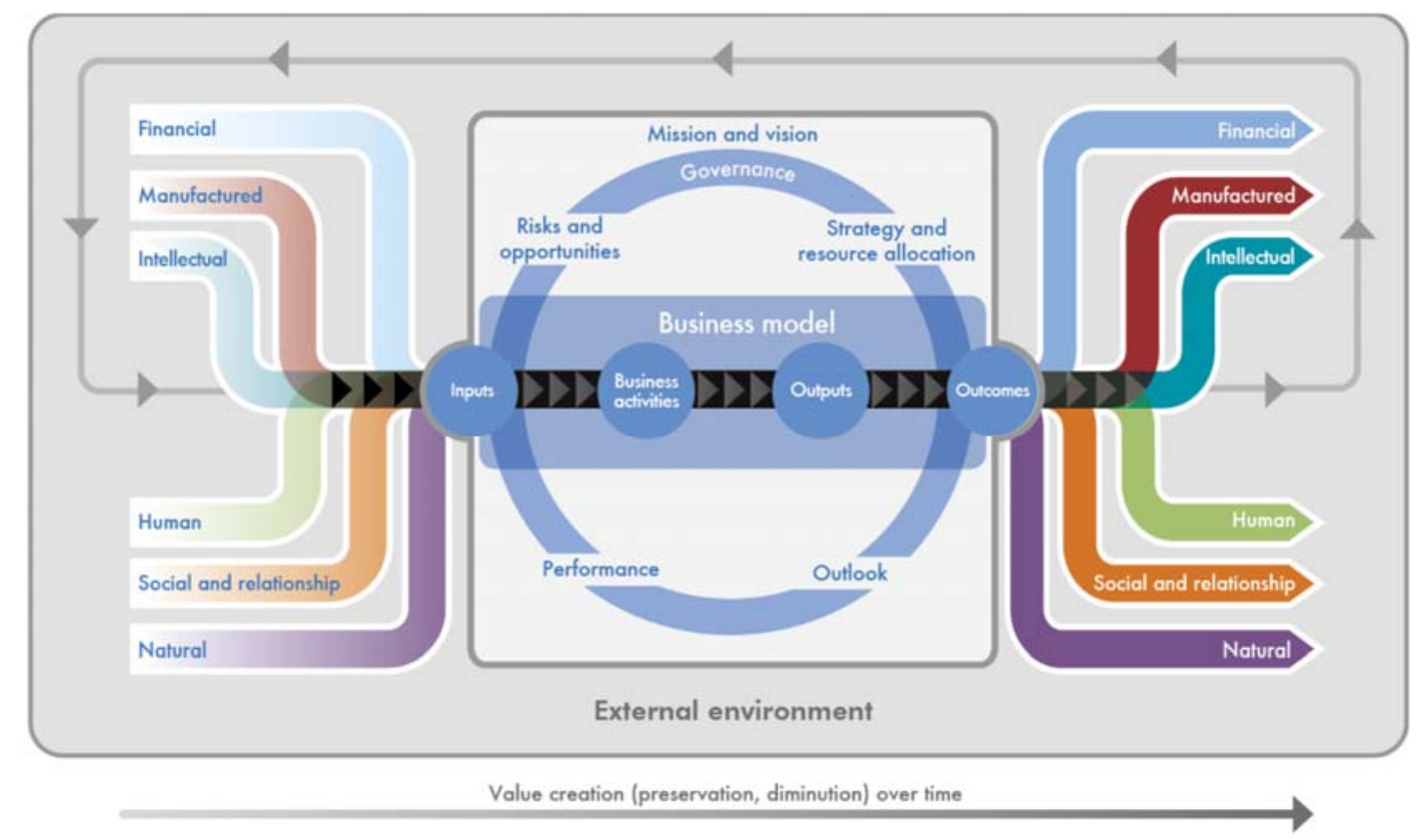

Copyright @ December 2013 by the International Integrated Reporting Council ('the IIRC'). All rights reserved. Used with permission of the IIRC. Contact the IIRC (info@theiirc.org) for permission to reproduce, store, transmit or make other uses of this document.

Addressing (2), the <IR > Framework lists "stakeholder relationships" as one of its seven Guiding Principles: “An integrated report should provide insight into the nature and quality of the organization's relationships with its key stakeholders, including how and to what extent the organization understands, takes into account and responds to their legitimate needs and interests” (IIRC, 2015: 5). Stakeholder engagement is essential for 
understanding stakeholders' interests and expectations. Striking the proper balance between stakeholders and shareholders, and amongst stakeholders themselves, requires recognizing that tradeoffs often exist due to interdependencies across choices. With proper engagement and a full and transparent explanation for why the company made the choices it did, stakeholders will accept the legitimacy of the decision even if they do not agree with it.

Key to (3), balancing the many and often competing interests of shareholders and a broad range of stakeholders, is the Guiding Principle of “connectivity of information”: “An integrated report should show a holistic picture of the combination, interrelatedness and dependencies between the factors that affect the organization's ability to create value over time” (IIRC, 2015: 5). What distinguishes an integrated report from a “combined report” is that the former shows the relationships, positive and negative, over specific time frames, between financial and nonfinancial performance. A combined report simply provides financial and nonfinancial information in a single document. Also key to (3) is the Guiding Principle of "materiality": "An integrated report should disclose information about matters that substantively affect the organization's ability to create value over the short, medium and long term” (IIRC, 2013: 33).

Materiality is a central, albeit somewhat elusive, concept in all three types of reporting. It is entity-specific, audience and timeframe-dependent, and based on human judgment. It is ultimately grounded in the judgment of the company's board of directors about whom it regards as the company's most significant audiences and the timeframes it uses to evaluate the impact the company has on them (for a fuller discussion of materiality see Eccles, Krzus, and Ribot, 2015: ch. 6). Materiality is different from what is "socially significant," although the two are often confused-as when a company produces a "Materiality Matrix.” A company can only determine what is material for itself -not for others- even as it can and should form a view about the absolute and relative level of importance different stakeholders accord ESG issues.

Materiality raises one of the central questions about integrated reporting: its relationship to sustainability reporting. Many have the mistaken notion that integrated reporting will 
lead to a single report that contains both financial and nonfinancial information and that sustainability reporting will no longer be necessary. This is not true. The integrated report contains information that is material based on the company's designated significant audiences and timeframes. The sustainability report contains information on the company's nonfinancial performance that it believes to be of importance to society, as represented by the stakeholder groups it deems as important but not significant—at least for now-to its value creation process.

In terms of (4), an increasing number of investors, although still a minority, are seriously working to incorporate ESG issues and a company's performance on them into their own decision-making processes. This has always been true for Socially Responsible Investment funds, but now “mainstream” investors, such as large pension funds and institutional asset managers, are starting to do so as well - even if they do this from a value rather than values perspective. One complaint typically made by investors interested in "ESG integration" is that they are not getting the data they need from the company to do so. Integrating it into decisions involves struggling with finding the material information relevant to them in a separate sustainability report and then combining it with the voluminous information found in the company's financial report. A well-done integrated report, based on the Guiding Principle of "conciseness," solves this problem: "An integrated report includes sufficient context to understand the organization's strategy, governance, performance and prospects without being burdened with less relevant information” (IIRC, 2015: 21). The integrated report is the way in which the company communicates its performance across all relevant financial, environmental, social, and governance dimensions so that investors can take an integrated view as well.

Finally, there is the issue of timeframe - of the need for longer-term thinking on the part of both companies and investors. The shorter the timeframe under consideration, the greater the tradeoffs between different types of performance and the interests of shareholders and other stakeholders are. With longer-term thinking, companies can make the investments necessary to improve both financial and nonfinancial performance, but they need patient investors in order to do. Companies routinely complain about their 
obligation to operate under short-term earnings pressure from their investors, while simultaneously reinforcing this attitude by providing guidance on quarterly earnings targets. Investors complain that companies do not provide them with sufficient information to be comfortable taking long-term positions, while eagerly anticipating the next earnings call. The Guiding Principle of "strategic focus and future orientation” is relevant here: “An integrated report should provide insight into the organization's strategy, and how it relates to the organization's ability to create value in the short, medium and long term and to its use of and effects on the capitals" including "how the organization balances short, medium and long term interests” (IIRC, 2013: 16).

While conceptually integrated reporting appears to be the right type of corporate reporting for a re-imagined capitalism, it can only play this role if it is practiced by virtually all companies. At the least, all large, publicly listed ones must practice it. Making this a reality is no simple feat. As noted, the only country to require integrated reporting is South Africa, and the rigor with which this is enforced falls far below what is required for financial reporting. One explanation for this relative lassitude is the lack of a consensus on frameworks and nonfinancial measurement standards. Another is the understandable unwillingness of regulators to specify standards at this early stage of the development of this new type of corporate reporting. Even if South Africa and other countries were to mandate integrated reporting as prescriptively as financial reporting is mandated, there would be the additional challenge of reconciling the reporting model across countries. It was not that long ago that each country had its own version of (Generally Accepted Accounting Principles) GAAP. Two major ones now dominate: the more rules-based U.S. GAAP under FASB, and the more principles-based International Financial Reporting Standards under the IASB. The “convergence” initiative to create one global set of accounting standards has been a long, difficult, and as of yet an unfinished process.

In the short term, it is best to let market forces work—for investors to demand integrated reporting by companies, in whatever form it comes, and for companies to respond to these demands. During this time, further work will be done to improve frameworks and standards for measuring and reporting on nonfinancial information. Ultimately, the State will have to intervene in some fashion in order to ensure broad-based adoption. Broadly 
speaking, this could happen in two ways. Regulators responsible for financial reporting could expand their mandate to integrated reporting. In the U.S., this would be the Securities and Exchange Commission (SEC). The alternative is for new legislation to be enacted, such as the EU's CSR Reporting Directive. We will consider each of these in turn.

\section{The SEC and Integrated Reporting}

The Securities Act of 1933 and the Securities Exchange Act of 1934 established the Securities and Exchange Commission. Its mission is to promote the public interest by protecting investors, facilitating capital formation, and maintaining fair, orderly, and efficient markets. Transparency is the main regulatory mechanism to ensure the correct evaluation and pricing of securities in the marketplace-the information function of reporting-which is the primary intent of the SEC. But there is also a modest transformation function, since reporting is intended to steer business behavior by exposing corporate conduct to public supervision. We say “modest” because financial reporting, the province of the SEC, is intended to spur companies to better performance as financial results are, more or less, reflected in their stock price.

The SEC has well-established standards for transparency, including monitoring and enforcement mechanisms. Its definition of materiality is consistent with that of integrated reporting. More recently, it has extended its traditional focus on financial information to include selected types of nonfinancial information. Thus, it is not inconceivable that the SEC could support the adoption of integrated reporting in the U.S. That said, since the SEC defines its role primarily in terms of the information function, the transformational aspects of integrated reporting would depend on how shareholders and other stakeholders react to the SEC's support of integrated reporting and, in turn, how companies respond to their desire for engagement.

The disclosure requirements for registered securities are contained in Regulation S-K (see http://www.ecfr.gov/cgi-bin/text-idx?node=pt17.3.229) or Regulation S-B for small 
businesses (For securities' reports, information must be disclosed that is: (1) specifically required under Regulation S-K or necessary to ensure that required disclosures are not misleading, and (2) material to investors' or shareholders' decision-making processes in accurately valuing securities (emphasis added). The Supreme Court of the United States defined what shall be considered "material" for securities reporting. A fact is material if "there is a substantial likelihood that a reasonable investor would consider it important" and would have viewed the information "as having significantly altered the 'total mix' of information made available.” (U.S. Supreme Court (1988) Basic Inc. v. Levinson. 485 U.S. 224, 238; emphasis added) This "requires delicate assessments of the inferences a 'reasonable shareholder' would draw from a given set of facts and the significance of those inferences to him.” (ibid.) Note that the Supreme Court's definition is not restricted to financial information; if a "reasonable investor" thinks quantitative or even qualitative nonfinancial information is important in the "total mix" of information, it should be disclosed. Regarding contingent and forward-looking information, the Supreme Court requests to balance "the indicated probability the event will occur and the anticipated magnitude of the event in the light of the totality of company activity.” (ibid., emphasis added). Changing social expectations may thus influence this assessment of "materiality," just as it is changing social expectations that have created the call to re-imagine capitalism. The Supreme Court's definition of materiality can clearly accommodate this.

The SEC has already provided guidance on specific types of nonfinancial information in its “Commission Guidance Regarding Disclosure Related to Climate Change” (SEC, 2010) and the Division of Corporation Finance drafted in its CF Disclosure Guidance: Topic No. 2 Cyber-Security (SEC, 2011) interpretive guidance on how existing securities regulations, in particular Regulation S-K, may require disclosure of information relating to climate change or cyber-security matters where they are material to the issuer or any of its business segments. Each piece of guidance discusses how the costs of compliance with laws and regulations to prevent and mitigate risks related to climate change and cyber-security may result in material expenses to be included in the financial disclosures. Both detail how the descriptions of items 101 (description of business), 103 (legal proceedings), 303 (management's discussion and analysis), 307 (disclosure controls and procedures), and 503(c) (risk factors) may compel issuers to address climate change or cyber-security risks or incidents. The International Corporate Accountability Roundtable 
(ICAR) has requested that the SEC promulgate similar interpretive guidance or rulings for human rights issues.

It is clear that under Regulation S-K, and with its definition of materiality, the SEC has the authority to potentially provide strong support for integrated reporting. Exactly what form this would take and when it would (and should) happen is not clear. While the mission of the SEC is to protect investors through, among other things, transparent corporate disclosures, it also has to balance the costs these disclosures impose on companies with the benefits to investors, who ultimately bear these costs. In general, the corporate community resists additional disclosures for both valid (rarely are required disclosures eliminated even when they are no longer relevant) and self-serving (more disclosure creates more accountability) reasons. For example, there was a strong negative reaction against the guidance on climate change although the SEC really just said "go reread Regulation S-K and think about it in the context of climate change.”

Thus, it is highly unlikely that the SEC would do anything like revise its instructions on the Form 10-K (Form 20-F for foreign registrants) filing to be based on the International $<$ IR $>$ Framework. Instead, it would issue guidance in the spirit of integrated reporting within its existing regulatory regime. For example, it could issue a guidance statement on the six capitals, or perhaps one on natural capital and one on the intangible assets of intellectual, human, and social and relationship capital. Similarly, it could issue a guidance statement reminding companies that "material" includes nonfinancial information and cite SASB as one source for input since its standards have been specifically designed for the Form 10-K (Form 20-F) filing. Should this happen, it is our view that a big step would be taken in the U.S. towards the practice of "pure" integrated reporting. Since the requirements for what information should be included in the Form 10-K (Form 20-F) are detailed and prescriptive, few meet the $<\mathrm{IR}>$ Framework's Guiding Principle of "conciseness." However, the company could accomplish this by simply making its annual report, which is not an official filing document, an annual integrated report that more closely follows the $<\mathrm{IR}>$ Framework. Once a company has crossed the Rubicon of including all material ESG issues in its Form 10-K (Form 20-F), based on, say, SASB guidance, it will have substantially laid the groundwork for turning its annual 
report into an integrated report. The latter will require a more narrative discussion about "connectivity of information" and perhaps a bit more "strategic focus and future orientation.”

\section{The EU and Integrated Reporting}

The alternative to an existing regulatory body providing support for integrated reporting is new regulation or even legislation from the domain of "sustainability" that is not tied to the complex apparatus of financial reporting regulations. To some extent this is already happening. In a joint 2013 report called "Carrots and Sticks,” KPMG, the Centre for Corporate Governance in Africa, Global Reporting Initiative, and the United Nations Environment Program considered some 180 policies in 45 countries. The study reported finding that, by 2013, 72\% of the policies had become mandatory, as compared with $62 \%$ of the policies in 32 countries examined in 2010, and 58\% of the policies in 19 countries in 2006 (KPMG, 2013).

The most important example of legislation in support of the disclosure of nonfinancial information is Directive 2014/95/EU ("CSR Reporting Directive") of 22 October 2014 amending Directive 2013/34/EU as regards disclosure of non-financial and diversity information by certain large undertakings and groups (European Council, 2014). It follows up on EU Directive 2013/34/EU of 26 June 2013 on the annual financial

statements, consolidated financial statements and related reports of certain types of undertakings which concerns country-by-country-reporting of company payments to governments in resource rich countries. Directive 2014/95/EU has to be implemented by the Member States by 6 December 2016 (Spiesshofer, 2014a). The CSR Reporting Directive expands the reporting requirements to a wide range of enterprises and subjects: it requires companies concerned to disclose in their management report information on policies, risks, and outcomes as regards environmental matters, social and employee aspects, respect for human rights, anticorruption and bribery issues, and diversity in their board of directors. This will provide investors and other stakeholders with a more comprehensive picture of a company's performance (European Commission, 2014). This 
information is to be included in the company's annual report. The Directive has high expectations for the benefits of this legislation (European Commission, 2014):

Each individual company disclosing transparent information on social and environmental matters will realise significant benefits over time, including better performance, lower funding costs, fewer and less significant business disruptions, better relations with consumers and stakeholders. Investors and lenders will benefit from a more informed and efficient investment decision process. Society at large will benefit from companies managing environmental and social challenges in a more effective and accountable way.

The European Commission (2014) argues that the above benefits cannot be realized by relying solely on voluntary reporting by companies. It states that only around $10 \%(2,500)$ of large EU companies are reporting on their environmental and social performance. This number will rise to some 6,000 companies under the new Directive.

The reporting on nonfinancial and diversity issues is not entirely new. Large enterprises have already been required to include nonfinancial performance indicators like information on environmental and employment issues in the annual report to the extent they are necessary for the evaluation of the company. The new CSR Reporting Directive goes beyond value assessment and shareholder and investor information and financial performance. It is a paradigm shift insofar as it is designed to direct business conduct by introducing due diligence and "knowing and showing" requirements, not only with regard to the CSR-compliance of the company or group, but also with regard to the supply chain (see Spiesshofer 2014). Targets include economic stakeholders like shareholders, bond holders, and creditors, as well as civil society and the general public, which shall be enabled to supervise and eventually enforce proper business reporting and conduct. Thus, the CSR Reporting Directive not only serve the information function, but also focuses on transformation.

The purpose of the Directive is not only risk assessment and risk management for the company and proper description of value-relevant factors. It also includes the avoidance of negative "impacts" - the soft steering of business conduct below the threshold of a 
violation of laws and regulations. The regulatory function of reporting is "know and show," i.e., to learn about causally-linked negative impacts, to develop avoidance or mitigation strategies, and to show this to the general public and stakeholders. In its considerations, the Directive recommends to Member States to enable all persons and organizations having a "legitimate interest" to enforce compliance with this Directive. Although it is not spelled out in the Directive, this could include citizen lawsuits and private enforcement actions by potentially affected parties or NGOs - all examples of the engagement process inherent in the transformation function. The other purpose of the Directive is to enhance consistency and comparability of nonfinancial information disclosed throughout the European Union, albeit respecting the diversity of CSR guidelines and approaches taken by enterprises (which is tantamount to trying to square the circle). The reporting on diversity in the Corporate Governance Declaration will, in a kind of "self-name-and-shame exercise," force companies to diversify the whole top management level—a particular target of transformation.

The requirement to measure impact raises yet another category of reporting in addition to activities and results. Activities lead to results that have impacts on an audience outside the company. Stock price is an example of the impact of financial performance on investors. Impacts can be positive (e.g., the social wealth created by new jobs) or negative (e.g., global warming caused by carbon emissions). Impacts are typically even more difficult to measure than are the results of nonfinancial performance. For example, those in the field of "impact investing" struggle to set standards for measures just as others are working to establish standards for nonfinancial information. Impact measurement can have both an information (e.g., by influencing the decisions of others regarding the company, such as buying its stock or products or taking a job there) and transformation (e.g., when a group mobilizes around impacts to reward or punish a company for the impacts it is creating) function.

Consideration 7 of the Directive contains differentiated guidance concerning the materiality of information, introducing a certain amount of ambiguity regarding which information should be reported. The report shall describe the actual and foreseeable impacts on the environment and on health and safety, and on the energy and water 
consumption. It can describe with regard to social and employee matters the implementation of essential ILO-Conventions, respect for trade union and workers' rights, social dialogue, and dialogue with local communities. With regard to human rights and anti-corruption, the report could contain information regarding the avoidance of human rights violations and corruption. Consideration 8 classifies the issues with respect to risk intensity: adequate information is required with regard to those factors which will lead most probably to the realization of essential risks with significant impacts. The materiality depends on the magnitude and severity of the negative impacts. This qualification is similar to the stipulation of the U.S. Supreme Court. Although the urgency to report is differentiated, the purpose is impact and thus transformation-oriented.

According to the Directive, the Member States shall provide that enterprises may base their reporting on national, EU, or international guidelines such as the UN Global Compact, the UN Guiding Principles on Business and Human Rights, the OECDGuidelines for Multinational Enterprises, ISO 26000 Guidance on Social Responsibility, GRI, or other recognized international guidelines like those of the IIRC. Although not mentioned by name, SASB would qualify and this Directive provides an opportunity to spread the adoption of these standards. The Directive stipulates that enterprises shall describe which guideline they have used for the reporting. As these guidelines vary widely in terms of scope, specification, issues covered, and methodology, it is not evident how consistency and comparability of the reports across the EU will be achieved (Spiesshofer, 2014a). We note that comparability is more important for the information function for the same reasons it is important for financial reporting. Investors want to compare the performance of companies, at least within a sector, in choosing if and how much to invest in any of them. In the transformation function, effective engagement can take place simply based on targeting performance improvements in a company, however it chooses to measure an activity, outcome, or impact.

The Directive has been criticized for a number of reasons: Reporting requirements are introduced without developing homogenous substantive standards of "expected behavior" first. Consistency and comparability are hard to achieve with substantial flexibility for the Member States regarding opt-out possibilities, the report-or-explain approach, and a 
variety of possible guidelines on which the reporting can be based. The reporting of negative "impacts" encompassing the whole supply chain is potentially endless and connected with potentially significant costs (Spiesshofer, 2014a). The Directive emphasizes that it is not about integrated reporting but clearly acknowledges that it could be a step in that direction (http://europa.eu/rapid/press-release_MEMO-14-301_en.htm; accessed August 2015):

The Directive focuses on environmental and social disclosures. Integrated reporting is a step ahead, and is about the integration by companies of financial, environmental, social and other information in a comprehensive and coherent manner. To be clear, this Directive does not require companies to comply with integrated reporting. The Commission is monitoring with great interest the evolution of the integrated reporting concept, and, in particular, the work of the International Integrated Reporting Council.

However, one of the challenges the EU will face should it decide to do so is in clarifying the question of audience. The current Directive is a kind of "all things for all people,” failing to distinguish between material issues for integrated reporting vs. the socially significant ones for sustainability reporting. As noted above, the Directive is ambiguous regarding the underlying concept of materiality on which it is based. Nevertheless, nothing in the legislation would preclude a company from making its own definition of materiality. Furthermore, since the detailed implementation of the Directive will be determined by each Member State, individual countries could decide to recommend the International $<\mathrm{IR}>$ Framework as the basis for complying with this Directive. We regard this as unlikely, at least in the short term, for the same reasons as discussed regarding the SEC if the Member State chooses its securities regulator as the entity responsible for implementing the Directive in its own country. However, how the implementation occurs and which entity is responsible for it will be decided by each Member State, and this could result in substantial variation. Despite these qualifications, the CSR Reporting Directive could turn out to be an important step towards integrated reporting in the EU over the long term and perhaps more quickly in certain Member States should they decide to do so. 


\section{Towards the Universal Adoption of Integrated Reporting}

We conclude this chapter facing a dilemma. On the one hand, it is clear that integrated reporting can play a central, even pivotal, role in bringing about a re-imagined capitalism. This can only happen at a system level through nearly universal adoption of integrated reporting - at least amongst the largest companies in the world that control the vast bulk of economic activity. Voluntary adoption is unlikely to achieve this objective in a meaningful timeframe. This would suggest a regulatory solution: the other side of the dilemma. Our discussion of the U.S. and the EU makes it clear that such regulation is unlikely to happen. Even if it did, the result could become a mere "tick-the-box" compliance exercise, achieving in only a minimalist way the information function of reporting and losing the transformation function so vital to achieving a re-imagined capitalism.

So what can be done? We begin by noting again that integrated reporting is not a silver bullet. Many other things must happen as well, including integrated: asset management, asset ownership, investment legal duties, proxy voting, corporate governance, corporate brokerage, investment consulting, financial literacy, and financial regulation (Waygood, 2015). All of these can help spread the adoption of integrated reporting; integrated reporting, in turn, can contribute to each of these. The causal relationships are many and complex; there is no simple, single, linear path to take. Furthermore, the most promising path will vary by country. In some countries, regulatory forces will play a stronger role. In others, it will be market forces. Both will be necessary in all countries. From this perspective, we have four common sense incremental recommendations relevant all over the world. We say incremental because these recommendations are based on existing regulatory regimes. However, we believe that ultimately a non-incremental outcome can be achieved once the proper groundwork has been laid.

First, companies should strive to implement the concepts in the $<\mathrm{IR}>$ Framework, leveraging the work of SASB, into their relevant official filing documents, such as the Form 10-K or Form 20-F, the new Strategic Report now required of U.K. listed 
companies, and the annual report. The old adage, “don't let the perfect be the enemy of the good," applies here. Rather than focusing on an integrated report as a particular type of report that needs to be structured in a particular way, companies should start to practice integrated thinking in the context of the five characteristics of a re-imagined capitalism described above. They should simply adapt their existing reporting practices as best they can.

Second, asset owners, asset managers, and sell-side analysts should encourage companies to practice integrated thinking in their communications with them. They should also, and again on an incremental basis, start practicing more integrated thinking themselves. This means they need to go beyond having separate "ESG teams" to having their sector specialists develop a view on what the material ESG issues are and how they can affect financial performance.

Third, the accounting community should move from mere advocacy for integrated reporting to actually helping to spread its adoption. This means that the audit professionals, not simply the advisory or consulting professionals (which is largely the case to date), need to have proactive conversations about integrated reporting with the CEO, CFO, and board of directors of the companies they audit. The auditors also need to become better informed about what information investors want, since they are the ultimate clients.

Fourth, the International Organization of Securities Commissions (IOSCO), "the international body that brings together the world's securities regulators and is recognized as the global standard setter for the securities sector," should establish a task force to publish a report on how securities commissions can support integrated reporting within their existing regulatory regime (IOSCO, 2015). These recommendations will support the first three recommendations as they lay the groundwork for the timing and nature of new legislation and regulation to support integrated reporting. 
The road to universal adoption of integrated reporting is a long one, but it is one that must be traveled. Our desire is that we achieve this objective by 2025. We will play whatever part we can to make that happen. 


\section{References}

Eccles, R. G., Krzus, M. P., and Ribot, S. (2015). The Integrated Reporting Movement: Meaning, Momentum, Motives, and Materiality. Hoboken, NJ: John Wiley \& Sons.

Eccles, R. G., and Serafeim, G. (2015). “Corporate and Integrated Reporting: A Functional Perspective.” In S. Mohrman, J. O'Toole, and E. Lawler (eds.), Corporate Stewardship: Organizing for Sustainable Effectiveness. Sheffield, UK: Greenleaf Publishing.

European Commission. (2014). Disclosure of non-financial and diversity information by large companies and groups - Frequently asked questions, Brussels, April 15, 2014. Available from: http://europa.eu/rapid/press-release MEMO-14-301 en.htm; accessed August 2015].

European Council (2013). EU Directive 2014/95/EU of 22 October 2014 amending Directive 2013/34/EU as regards disclosure of non-financial and diversity information by certain large undertakings and groups ("CSR Reporting Directive”), adopted by the Council of the European Union on September 29, 2014, OJ L 330, 15.11.2014, p. 1-9.

International Integrated Reporting Council (IIRC). (2013). The International $<I R>$ Framework. Published December 2013, Copyright 2015.

IOSCO. (2015). IOSCO: About IOSCO. Available from: https://www.iosco.org/about/?subsection=about iosco; accessed August 2015.

KPMG Advisory N.V. (2013). "Carrots and Sticks: Sustainability Reporting Policies Worldwide - Today's Best Practice, Tomorrow' Trends.” Global Reporting Initiative, Unit for Corporate Governance in Africa, pp. 1-96.

Securities and Exchange Commission (SEC) (2007). Securities Act Rule 408 and Exchange Act Rule 12b-20. Available from: https://www.sec.gov/rules/final/2007/338876.pdf; accessed August 2015.

Securities and Exchange Commission (SEC) (2010). "Climate Change Guidance.” SECURITIES AND EXCHANGE COMMISSION: 17 CFR PARTS 211, 231 and 241 [Release Nos. 33-9106; 34-61469; FR-82], Commission Guidance Regarding Disclosure Related to Climate Change. Feb 8, 2010. Available from: https://www.sec.gov/rules/interp/2010/33-9106.pdf.; accessed August 2015.

Securities and Exchange Commission (SEC) (2011). "Cyber Security Guidance.” CF Disclosure Guidance: Topic No. 2 Cyber-Security. Available from: https://www.sec.gov/divisions/corpfin/guidance/cfguidance-topic2.htm; accessed August 2015.

Spiesshofer, B. (2014a). Die neue europäische Richtlinie über die Offenlegung nichtfinanzieller Informationen - Paradigmenwechsel oder Papiertiger? [The New 
European Directive on the Disclosure of Nonfinancial Information: Paradigm Shift or Paper Tiger?]. Neue Zeitschrift für Gesellschaftsrecht 33/2014 (A): 1281-87.

Spiesshofer, B. (2014). Wirtschaft und Menschenrechte - rechtliche Aspekte der Corporate Social Responsibility [Business and Human Rights - Legal Aspects of CSR]. Neue Juristische Wochenschrift 34/2014, (B): 2473-2479.

U.S. Supreme Court (1988). Basic Inc. v. Levinson. 485 U.S. 224, 238.

Waygood, S. (2015). “A Roadmap for Sustainable Capital Investments: An Aviva White Paper.” Aviva Investors: 1-60. 